\title{
Autogenic Succession in a Subtropical Savanna: Conversion of Grassland to Thorn Woodland
}

\author{
Steve Archer; Charles Scifres; C. R. Bassham; Robert Maggio \\ Ecological Monographs, Vol. 58, No. 2. (Jun., 1988), pp. 111-127.
}

Stable URL:

http://links.jstor.org/sici?sici=0012-9615\%28198806\%2958\%3A2\%3C111\%3AASIASS\%3E2.0.CO\%3B2-Q

Ecological Monographs is currently published by Ecological Society of America.

Your use of the JSTOR archive indicates your acceptance of JSTOR's Terms and Conditions of Use, available at http://www.jstor.org/about/terms.html. JSTOR's Terms and Conditions of Use provides, in part, that unless you have obtained prior permission, you may not download an entire issue of a journal or multiple copies of articles, and you may use content in the JSTOR archive only for your personal, non-commercial use.

Please contact the publisher regarding any further use of this work. Publisher contact information may be obtained at http://www.jstor.org/journals/esa.html.

Each copy of any part of a JSTOR transmission must contain the same copyright notice that appears on the screen or printed page of such transmission.

The JSTOR Archive is a trusted digital repository providing for long-term preservation and access to leading academic journals and scholarly literature from around the world. The Archive is supported by libraries, scholarly societies, publishers, and foundations. It is an initiative of JSTOR, a not-for-profit organization with a mission to help the scholarly community take advantage of advances in technology. For more information regarding JSTOR, please contact support@jstor.org. 


\title{
AUTOGENIC SUCCESSION IN A SUBTROPICAL SAVANNA: CONVERSION OF GRASSLAND TO THORN WOODLAND ${ }^{1}$
}

\author{
Steve Archer, Charles Scifres, and C. R. Bassham \\ Range Science Department, Texas A\&M University,
}

AND

\author{
RoBert Maggio \\ Forest Science Department, Texas A\&M University, College Station, Texas 77843 USA
}

Abstract. Dense thorn woodlands occupy what are thought to have been grasslands and savannas prior to settlement of the Rio Grande Plains of Texas. However, the tenet that grasslands have been converted to shrublands and woodlands in recent history is controversial and based largely upon conflicting historical accounts. Our objective was to determine how the presumed physiognomic conversion from grassland or savanna to woodlands might have occurred.

Some upland landscapes are dominated by closed-canopy woodlands in southern Texas, whereas others have a two-phase pattern of discrete shrub clusters scattered throughout a grassland. More mesic sites are dominated by closed-canopy woodlands. We hypothesized the two-phase landscapes represented an intermediate stage in the conversion of grassland to woodland. As new shrub clusters were initiated and existing clusters expanded and coalesced, a gradual shift from grassland to savanna to woodland would occur. To address this hypothesis, we inventoried herbaceous interspaces for woody colonizers, quantified the composition and distribution of shrub clusters on upland sites, and compared the structure of clusters to that of adjacent, more mesic areas with continuous woody plant cover. To assess the physiognomic stability of the two-phase landscapes, cluster size, density, and cover were quantified for 1941, 1960, and 1983 from aerial photographs.

A lone mesquite (Prosopis glandulosa) plant occurred in $>80 \%$ of the upland clusters, where it was typically the largest individual in terms of basal area, height, and canopy area. The number of woody species per cluster ranged from 1 to 15 and was strongly related to mesquite basal diameter $\left(R^{2}=0.86\right)$. Cluster diversity, evenness, and size were also significantly correlated with mesquite size. The data suggest that mesquite plants invaded grasslands and served as recruitment foci for bird-disseminated seeds of other woody species previously restricted to other habitats. The result was a landscape composed of discrete chronosequences of woody plant assemblages organized about a mesquite nucleus.

Within the two-phase portion of the landscape, $50 \%$ of the clusters were within $5 \mathrm{~m}$ of another and $95 \%$ were within $15 \mathrm{~m}$ of another. Analysis of the size class distribution of clusters suggested that most had yet to realize their growth potential. Moreover, the herbaceous clearings between clusters contained high densities of woody seedlings, mostly $(>70 \%)$ mesquite, which occurred in $85 \%$ of the clearings, with a mean density of 350 plants/ha. Coalescence will become increasingly probable if new clusters are initiated and existing clusters expand. This phenomenon appeared to be in progress on one portion of the landscape and had apparently already occurred on others. As clusters developed on the two-phase portion of the landscape, their species composition, dominance, and size class structure became increasingly similar to that of adjacent closed-canopy woodlands on more mesic sites.

Mean cluster size increased from $494 \mathrm{~m}^{2}$ in 1941 to $717 \mathrm{~m}^{2}$ in 1983 . Growth rates of clusters were a function of cluster size and precipitation. During the 1941-1960 period characterized by severe drought, there was a slight decrease in total woody plant cover resulting primarily from the formation of gaps among clusters on the periphery of the site and a $35 \%$ decrease in density of clusters $<5 \mathrm{~m}^{2}$. These cover losses offset the areal expansion of small $\left(<100 \mathrm{~m}^{2}\right)$ clusters which had an average relative growth rate $(R G R)$ of $0.10 \mathrm{~m}^{2} \cdot \mathrm{m}^{-2} \cdot \mathrm{yr}^{-1}$. Post-drought woody plant cover increased from $8 \%$ in 1960 to $36 \%$ in $[983$ as new clusters were initiated (density increased from 16 to 26 clusters $/ \mathrm{ha}$ ), and the $R G R$ of small clusters increased to $0.16 \mathrm{~m}^{2} \cdot \mathrm{m}^{-2} \cdot \mathrm{yr}^{-1}$. Numerous clusters coalesced during this period. $R G R \mathrm{~s}$ of clusters $>100 \mathrm{~m}^{2}$ were an order of magnitude lower than those of clusters $<100 \mathrm{~m}^{2}$ in each time period. The $R G R$ of large clusters following the drought was not significantly increased, except in the largest size class (clusters $>1,000 \mathrm{~m}^{2}$ ).

Our results indicate (1) mesquite invaded grasslands and served as the nucleus of cluster organization on upland sites; (2) woody plant community development has been highly punctuated by variations in precipitation; (3) clusters $>5 \mathrm{~m}^{2}$ in area are persistent features of the landscape; and (4) the present two-phase pattern is moving toward a monophasic woodland as new clusters are initiated and existing clusters expand and coalesce. As a result, (5) shrub clusters on uplands represent an intermediate stage in the conversion of grassland to woodland, and (6) closed-canopy woodlands on more mesic sites appear to represent portions of the landscape where this has already occurred. Because the conversion of grasslands and savannas to woodlands in the Rio Grande Plains is initiated by mesquite, factors regulating its dispersal, establishment, and role as a facilitator of woody community development are emphasized.

Key words: DECORANA; detrended correspondence analysis; diversity; facilitation; grazing; mesquite; mosaics; patterns; Prosopis glandulosa; Rio Grande Plains; size class distribution; species-area curve; Tamaulipan Biotic Province; Texas.

' Manuscript received 9 January 1987; revised 3 August 1987; accepted 21 August 1987. 


\section{INTRODUCTION}

Quantitative and historical assessments indicate woody plant abundance has increased substantially in grasslands during the last 50-300 yr in Africa (Kelly and Walker 1976, van Vegten 1983), Australia (Harrington et al. 1984), and North and South America (Buffington and Herbel 1965, Blackburn and Tueller 1970, Smeins 1983). Remaining grasslands may become increasingly susceptible to woody plant encroachment in response to anticipated global climatic changes (Emmanuel et al. 1985). Although encroachment of woody plants into grasslands has been widely recognized, the rates, patterns, and dynamics of the process have seldom been quantified.

In some instances, the shift from grassland to shrubland or woodland apparently resulted from recent and rapid increases in the stature and abundance of woody species within their historic ranges (e.g., mesquite [Prosopis glandulosa], Johnston [963). In other cases, gradual range extensions apparently occurred over long periods (e.g., creosotebush [Larrea tridentata], Hunziker et al. 1977, van Devender and Spaulding 1979). These physiognomic shifts have been attributed to changes in climate (e.g., Hastings and Turner 1965, Neilson 1986), fire frequency, and grazing (e.g., Bogusch 1952, Humphrey 1958, Lehman 1969, Madany and West 1983).

The Rio Grande Plains of southern Texas offer interesting examples of the grassland-to-shrubland conversion process. The potential natural vegetation of southern Texas and northern Mexico has been classified as Prosopis-Acacia-Andropogon-Setaria savanna (Kuchler 1964). However, the present vegetation is subtropical thorn woodland (Blair 1950, Davis and Spicer 1965). The contention that woody assemblages have displaced prairies and savannas in this region is controversial (Malin 1953) and has yet to be documented. Most evidence is from indirect, historical sources (Bogusch 1952, Humphrey 1958, Inglis 1964), many of which are conflicting. It is generally thought the geographic range of woody species such as Prosopis has changed little in the past 300-500 yr (Johnston 1963). However, anthropogenic disturbance (e.g., overgrazing), reduced fire frequencies, and drought have presumably interacted, perhaps against a backdrop of gradual climatic change, enabling mesquite and other woody plants to increase in stature and density on grasslands.

Many landscapes in the Rio Grande Plains are characterized by dense thorn woodlands, whereas others are grasslands with scattered clumps of woody plants. The distinctive two-phase character, an open, continuous phase (grassy matrix) and a discontinuous phase (discrete shrub clusters) (Fig. 1) described in detail by Whittaker et al. (1979a), also occurs in Australia (Whittaker et al. 1979b) and Chile (Fuentes et al. 1984, 1986). Field observations in Texas suggested shrub clusters on the two-phase landscapes were organized around a mesquite nucleus, and that monophasic woodlands on more mesic sites were formed from the coalescence of shrub clusters. We therefore hypothesized (1) the size, species composition, and diversity of clusters would be a function of mesquite size; (2) the two-phase pattern represents an intermediate stage in the conversion of a grassland to a woodland; and (3) closed-canopy woodlands on more mesic sites were mosaics of coalesced shrub clusters.

To test these hypotheses, we surveyed herbaceous clearings for invading woody plants and inventoried shrub clusters on a two-phase landscape to determine their origin, development, and distribution. We then compared the composition of clusters at advanced stages of development to that of an adjacent stand of closedcanopy woodlands. To assess the physiognomic stability of the two-phase landscapes, we examined aerial photographs from 1941,1960 , and 1983. Because of contrasting precipitation patterns between time periods, differences in patterns of cluster development were expected. One of the most severe droughts on record occurred in southern Texas during the 1950's (Carter 1964, Norwine 1978). In contrast, the 19601983 period was typified by normal to above-normal annual precipitation. We thus sought to (1) examine the rate and pattern of cluster development on the twophase portion of the landscape; (2) document the appearance of new clusters and the persistence and coalescence of existing clusters; and (3) relate cluster dynamics to variations in precipitation.

\section{STUDY AREA}

Field work was conducted on the Texas Agricultural Experiment Station, La Copita Research Area, $15 \mathrm{~km}$ from Alice, Texas $\left(27^{\circ} 40^{\prime} \mathrm{N}, 98^{\circ} 12^{\prime} \mathrm{W}\right)$ in the eastern Rio Grande Plains of the Tamaulipan Biotic Province (Blair 1950). Prior to its acquisition in 198 I, the 1093ha research area was a private cattle ranch owned by the same family since the mid-1800's. With the exception of a small (10-ha) tamegrass pasture, the area had not been mechanically or chemically manipulated.

The site was dominated by the arborescent legume honey mesquite (Prosopis glandulosa var. glandulosa Torr.), with various mixtures of broad-leaved evergreen and deciduous shrubs in its understory. Herbaceous vegetation between shrub clusters was composed of C4 grasses such as Paspalum setaceum, Setaria geniculata, Bouteloua rigidiseta, and Chloris cucullata, which give way to grasses such as Aristida spp., Bouteloua trifida, Cenchrus incertus, and Chloris verticillata under prolonged, heavy grazing by cattle. Plant nomenclature follows Correll and Johnston (1979).

Elevation on the site ranged from 75 to $90 \mathrm{~m}$. Climate of the region is subtropical with mild winters and hot summers. Mean annual temperature is $22.4^{\circ} \mathrm{C}$ and the growing season is $289 \mathrm{~d}$ (USDA 1979). Average annual rainfall is $68 \mathrm{~cm}$, with maxima in May and 
September. Data were collected on Miguel and Papalote Series fine loamy sites (hyperthermic aquic paleustalfs, $1-3 \%$ slopes). Contemporary vegetation of the region has been described by Davis and Spicer (1965).

\section{METHODS \\ Field sampling}

A shrub cluster was defined as any association of two or more shrub species (including cacti) having their combined canopies separated from those of other woody plants by an herbaceous clearing (see Whittaker et al. 1979a). Woody plant attributes measured on species in clusters included basal diameter of the largest stem, height, and canopy dimensions. Sampling was conducted in the spring and early summer of 1984 .

To determine if woody species were invading herbaceous clearings between shrub clusters, belt transects $2 \mathrm{~m}$ wide were inventoried for lone woody plants. Clearings ( $n=40$ ) were systematically selected from grids placed over aerial photographs so as to obtain uniform sampling of the area. A single transect was established in each clearing to traverse its greatest distance. Transects ranged in length from 24 to $62 \mathrm{~m}$. A total of four line-intercept transects, each $200 \mathrm{~m}$ long, were also established in the two-phase region. Dimensions of shrub clusters encountered along each transect were noted along with attribute data for the largest individual of each woody species in the cluster.

Because of the apparent importance of Prosopis in grassland clearings and its dominance in the great majority of shrub clusters, 56 clusters, each containing a live Prosopis plant, were selected for detailed description. Clusters representing the range of size classes observed on the area and meeting the live mesquite criterion were randomly selected in a manner similar to that of clearings and described to supplement the extensive landscape survey. Attribute data were obtained on every individual of each woody species for each of these clusters. In addition, distance from the largest (and usually the only) Prosopis plant to the cluster perimeter was measured in cardinal and intercardinal directions to quantify cluster shape, orientation, and areal extent. Shape and orientation of each cluster was determined by relativizing its dimensions in each of the eight directions:

$$
\begin{aligned}
& \text { relative distance } \\
& \text { from Prosopis to } \\
& \text { cluster perimeter }
\end{aligned}=\frac{\begin{array}{c}
\text { distance in a } \\
\text { given direction }
\end{array}}{\begin{array}{c}
\text { distance averaged } \\
\text { over eight directions. }
\end{array}}
$$

Values different from one in a given direction would indicate departure from circularity.

Diversity was estimated using $\exp \left(H^{\prime}\right)$, where

$$
H^{\prime}=-\sum p_{i} \ln p_{i}
$$

and $p_{i}$ was the relative canopy area of species $i$ in a cluster. $\operatorname{Exp}\left(H^{\prime}\right)$ was used rather than $H^{\prime}$ because the

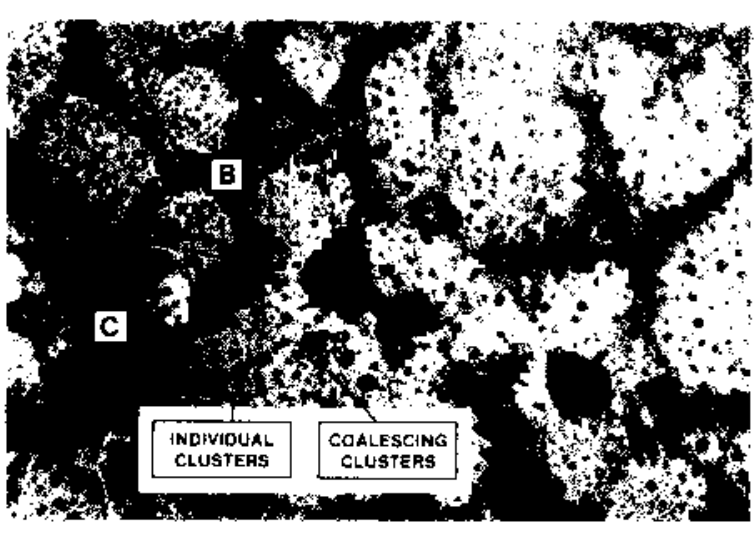

FIG. I. Aerial view of a two-phase pattern of discrete clumps of woody vegetation scattered throughout a grassy matrix (A). Bordering the two-phase portion of the landscape were monophasic woodlands associated with more mesic drainages (B) and low-centered polygons or playas (C). The clusters, which were organized about mesquite (Prosopis glandulosa), represent chronosequences whose species compositions at latter stages of development were similar to that of the closed canopy woodlands in region B. Largest clusters in the two-phase zone represent a mosaic of coalesced clusters.

former represents the number of equally common species in a sample (Peet 1974). Evenness $(E)$ was estimated using Alatalo's (1981) variation of Hill's ratio:

$$
E=\left(N_{2}-[) /\left(N_{1}-1\right),\right.
$$

where $N_{2}=1 / \sum p_{i}^{2}$ and $N_{1}=\exp \left(H^{\prime}\right)$.

Canopy area was summed by species for each of the 56 intensively sampled shrub clusters and transformed to an octave scale for multivariate analysis. Detrended correspondence analysis (DECORANA) (Hill 1979) was then used to ordinate the 56 clusters (sample units), which had a total of 20 woody species.

The insular nature of the shrub clusters suggested application of island biogeography theory to assess their stability with regard to species composition. The relationship developed by Preston (1962) was used:

$$
S=C A^{2}
$$

where species richness $(S)$ is an exponential function of cluster area in square metres $(A)$. The slope of the line relating $S$ and $A$ is given by $z$, while $c$ represents the $Y$ intercept. The $\log _{10}$ of $A$ is regressed on $\log _{10} S$ to generate $c$ and $z$.

Dense woodlands occurred in shallow, dry drainages surrounding upland sites (Fig. 1). The point-centered quarter technique (Cottam et al. 1953) was used to characterize these more mesic portions of the landscape. A total of 100 points were sampled at $5-\mathrm{m}$ intervals along each of 16 transects placed systematically around the perimeter of the two-phase region. At each point, basal diameter of the largest stem of the nearest 
woody species in each of three height categories $(<1$ $\mathrm{m}, \mathrm{l}-2 \mathrm{~m}$, and $>2 \mathrm{~m}$ ) was recorded in each quadrant.

\section{Aerial photography interpretation}

Three spatially distinct sites (SL, S2, and S3) within the research area were randomly selected for mapping. Each site was characterized by the same sort of polygonal vegetation pattern (Fig. 1). Higher elevation central portions of the polygons exhibited the two-phase vegetation pattern: clusters of shrubs (discrete phase) scattered throughout a grassland (continuous phase) (e.g., Whittaker et al. 1979a). Areal extent of the twophase pattern in 1941 was $13.7,8.6$, and 80.3 ha for $\mathrm{S} 1, \mathrm{~S} 2$, and $\mathrm{S} 3$, respectively. Encircling the region characterized by the two-phase vegetation pattern were monophasic, continuous woodlands dominated by $P$. glandulosa, Zanthoxylum fagara, and Celtis pallida. These border regions were ephemeral drainages $5-7 \mathrm{~m}$ lower in elevation than zones with two-phase patterning. The drainages appear to be late- or post-Pliocene tension faults produced by subsidence of the coastal area, which caused a fracturing of weak caliche limestone and Goliad sandstone formations (Barton 1933). Fracture drainage lines occurred independent of stream valleys, ridges, or uplands that they crossed, and lacked the meandering of small streams. Erosion presumably was accelerated along the fracture lines relative to the inter-fracture areas and disruption of the cemented caliche and sandstone appears to have favored deep-rooted woody plants.

Stereo pairs of aerial photographs were obtained for 1941 (1:14 450), 1960 (1:20000), and 1983 (1:19421) from the Soil Conservation Service/U.S. Department of Agriculture, in the form of $22.9 \times 22.9 \mathrm{~cm}$ positive transparencies. The 1983 photographs were color infrared and the others black and white. A 7.5-minute United States Department of the Interior Geological Survey quadrangle map was used to validate scales. Photographs were viewed stereoscopically under $10 \times$ magnification, and the outline of woody clusters traced onto frosted acetate overlays along with the perimeter of the wooded zone bordering the two-phase portion of the landscape. Within the two-phase area, a cluster was defined as an assemblage of woody vegetation with continuous canopy cover, surrounded by herbaceous vegetation. Woody clusters smaller than $\approx 3 \mathrm{~m}$ in diameter were noted as "point locations."

Photo overlays for each set of photographs were enlarged to a $1: 9000$ scale using a Krones reflecting projector. The areal extent of individual clusters and the two-phase patterning was determined by digitizing the overlays into a geographic information system (Maggio and Wunneburger 1986). Direct comparisons of the areal extent of clusters and the two-phase patterning was not possible, because of slight scale variations and the lack of distinctive control points on the three photography dates. However, among the three sites, 29 uniquely positioned clusters were identified and fol- lowed over time. Relative $(R G R)$ and absolute $(G R)$ growth rates of these clusters were calculated according to Hunt ([978):

$$
R G R=\left(\ln S_{2}-\ln S_{1}\right) /\left(t_{2}-t_{4}\right)
$$

and

$$
G R=\left(S_{2}-S_{1}\right) /\left(t_{2}-t_{1}\right)
$$

where $S_{1}$ was the cluster size $\left(\mathrm{m}^{2}\right)$ at time $t_{1}$, and $S_{2}$ the size of the cluster at time $t_{2}$.

Areas were computed for each cluster and summed. Crown diameters on $10 \%$ of the point locations were precisely measured for each date. The average area obtained for this subset $\left(\approx 4.5 \mathrm{~m}^{2}\right)$ was then assigned to all other point locations. Cluster and point location areas were summed to obtain total acreage of woody canopy cover within the two-phase region of each site. Because absolute size of sites differed greatly ( $8-80 \mathrm{ha}$ ), the areal coverage of woody clusters and points were expressed relative to the acreage characterized by the two-phase pattern at each point in time.

Total change in woody plant cover over time was represented by the combined change in areal extent of the two-phase region and the area occupied by clusters and points. For example, if clusters on the perimeter of the two-phase zone coalesced in to the woody border, the size of the two-phase area would decrease. At the same time, clusters might be increasing in size and density within the zone characterized by the two-phase pattern. These combined changes in ground area occupied by woody plants were calculated relative to 1941 for each site at each time as follows:

$$
\begin{aligned}
& \text { total woody plant cover }(\%) \\
& =\text { (two-phase area } 1941 \text { - current two-phase area } \\
& \quad+\text { current cluster area) } \\
& \quad \div \text { (two phase area } 1941)
\end{aligned}
$$

When the two-phase area in 1941 equalled the current two-phase area, as would be the case in 1941, total woody plant cover (\%) was simply the area occupied by clusters plus points, divided by the total area of two-phase patterning.

Descriptive statistics and analysis of variance were computed using the Statistical Analysis System (SAS 1982). A Kolmogorov-Smirnov test was used to determine whether the distribution of cluster sizes changed over time and Tukey's $Q$ procedure was used to test for significant $(P<.05)$ differences among means (Sokal and Rohlf 1981).

\section{Results \\ Woody plant invasion and cluster development}

A total of eight woody and two succulent species were encountered in the 40 herbaceous clearings sampled in 1984 (Table 1). Prosopis occurred in $85 \%$ of the clearings, with an average density of 350 live plants/ha. Prosopis density exceeded 300 live plants/ 
TABLE 1. Woody species inhabiting grassland clearings between shrub clusters. Data are from $2 \mathrm{~m}$ wide belt transects in 40 separate clearings. Three species, each with a frequency $<5 \%$, are not shown.

\begin{tabular}{|c|c|c|c|c|c|c|c|}
\hline \multirow[b]{3}{*}{ Species } & \multirow{2}{*}{\multicolumn{2}{|c|}{ No. of plants }} & \multicolumn{5}{|c|}{ Live plants } \\
\hline & & & \multirow{2}{*}{$\begin{array}{c}\text { Frequency* } \\
(\%)\end{array}$} & \multicolumn{2}{|c|}{ Density (plants/ha) } & \multicolumn{2}{|c|}{ Basal diameter $(\mathrm{cm})$} \\
\hline & Live & Dead & & Mean & (SE) & Mean & (SE) \\
\hline Prosopis glandulosa & 90 & 20 & 85 & 350 & $(40)$ & 0.9 & $(0.1)$ \\
\hline Opuntia lindheimeri & 25 & 0 & 43 & 100 & (20) & $\cdots$ & $(\cdots)$ \\
\hline Acacia farnesiana & 15 & 3 & 33 & 70 & (20) & 2.2 & $(0.8)$ \\
\hline Zanthoxylum fagara & 9 & 0 & 20 & 30 & (10) & 1.2 & $(0.2)$ \\
\hline Opuntia leptocaulis & 8 & 0 & 20 & 30 & (10) & $\ldots$ & $(\cdots)$ \\
\hline Coltubrina texensis & 8 & 0 & 17 & 30 & $(20)$ & 0.7 & $(0.1)$ \\
\hline Diospyros texana & 4 & 0 & 7 & 16 & (24) & 0.5 & $(0.1)$ \\
\hline
\end{tabular}

* Percentage of transects in which a given species was encountered $(N=40)$.

ha in $60 \%$ of the clearings. Of the live Prosopis plants in clearings, $88 \%$ had basal diameters $<2 \mathrm{~cm}$ (maximum $=4.2 \mathrm{~cm}$ ).

Distance between shrub clusters averaged $8.9 \mathrm{~m}$. Nearly $50 \%$ of the clusters were within $5 \mathrm{~m}$ of another cluster; $\approx 95 \%$ were within $15 \mathrm{~m}$ of another cluster. The landscape was dominated by clusters $<5 \mathrm{~m}^{2}$ in area (Fig. 2); thus, the potential for attaining larger sizes appeared high. More than $60 \%$ of the clusters contained 4-12 woody species (mean $=6.7$ ); two clusters each contained 15 woody species.

Prosopis occurred in a high percentage of all clusters, regardless of their species composition (Fig. 3). Opuntia lindheimeri and Zanthoxylum fagara were also common, but only in clusters with at least two and three species, respectively. Species such as Celtis pallida, Diospyros texana, and Condalia obovata had high frequencies of occurrence only when clusters contained at least 4-6 woody species. Shrubs such as Zizyphus and Berberis were consistently present only in the most species-rich clusters. Frequency of occurrence of Prosopis in clusters was underestimated, because several clusters contained large dead plants. When dead plants were included, overall frequency of occurrence of Prosopis in clusters increased to $83 \%$. There was typically only one Prosopis plant per cluster (mean $[ \pm \mathrm{SE}]=1.1$ $[ \pm 0.1] ; N=104$ ), and it was usually the largest plant, both in basal diameter and height $(88$ and $80 \%$ of the clusters, respectively).

All Prosopis plants with basal diameters $<1 \mathrm{~cm}$ were unassociated with other woody species. The percentage of Prosopis plants associated with at least one other species increased with increasing diameter until every Prosopis plant with basal diameter of $\geq 6 \mathrm{~cm}$ had at least one other woody species beneath its canopy. The number of woody species in the clusters increased linearly as Prosopis basal diameter increased to $10 \mathrm{~cm}$ (Fig. 4). Additions of woody species then decreased, with large clusters having a maximum of 15 species. The relationship between Prosopis size and the number of woody species per cluster was best described as:

species per cluster $=12.71[1-\exp (-0.05 B D)]$, where $B D$ was the basal diameter (in centimetres) of the Prosopis plant $\left(R^{2}=0.86 ; P<.001\right)$. The relationships in Eq. 8 and Fig. 4 were based on sampling $21 \mathrm{l}$ clusters having live Prosopis plants 65 clusters from line intercept transects, 56 intensively sampled clusters, and 90 lone Prosopis plants from belt transects). The relationship between species richness $(S)$ and cluster size ( $A$, in square metres) was:

$$
S=2.86 . A^{0.33}
$$

$\left(R^{2}=0.64 ; n=211 ; P<.001\right)$. However, a better relationship between richness and cluster size was obtained using the following equation:

$$
S=9.74(\mathrm{l}-\exp [-0.116 \mathrm{~A}])
$$

$\left(R^{2}=0.83\right)$.

Woody assemblages beneath Prosopis canopies were typically circular with no consistent orientation. The relative distance from the Prosopis plant to cluster edge

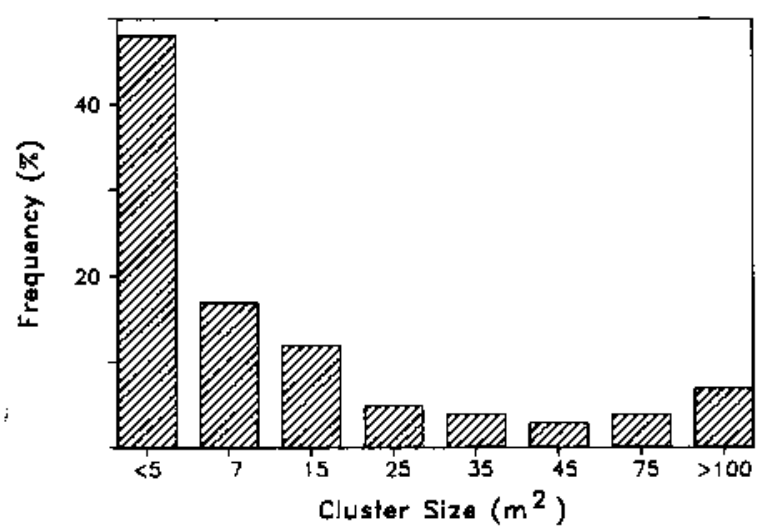

Fig. 2. Size class distribution of woody plant clusters on a fine loamy upland site $(N=104)$. Clusters were typically circular in shape, and area was calculated treating clusters as circular. Diameter was derived by averaging the long axis of the cluster and the greatest distance in the direction perpendicular to the long axis. These estimates were corrected as follows: Log Actual Area $=0.58+0.79$ Log Estimated Area $\left(R^{2}=0.80 ; p<.01\right)$. This correction factor was obtained from field measurements of the circumference of 50 clusters spanning the range of size classes observed. 


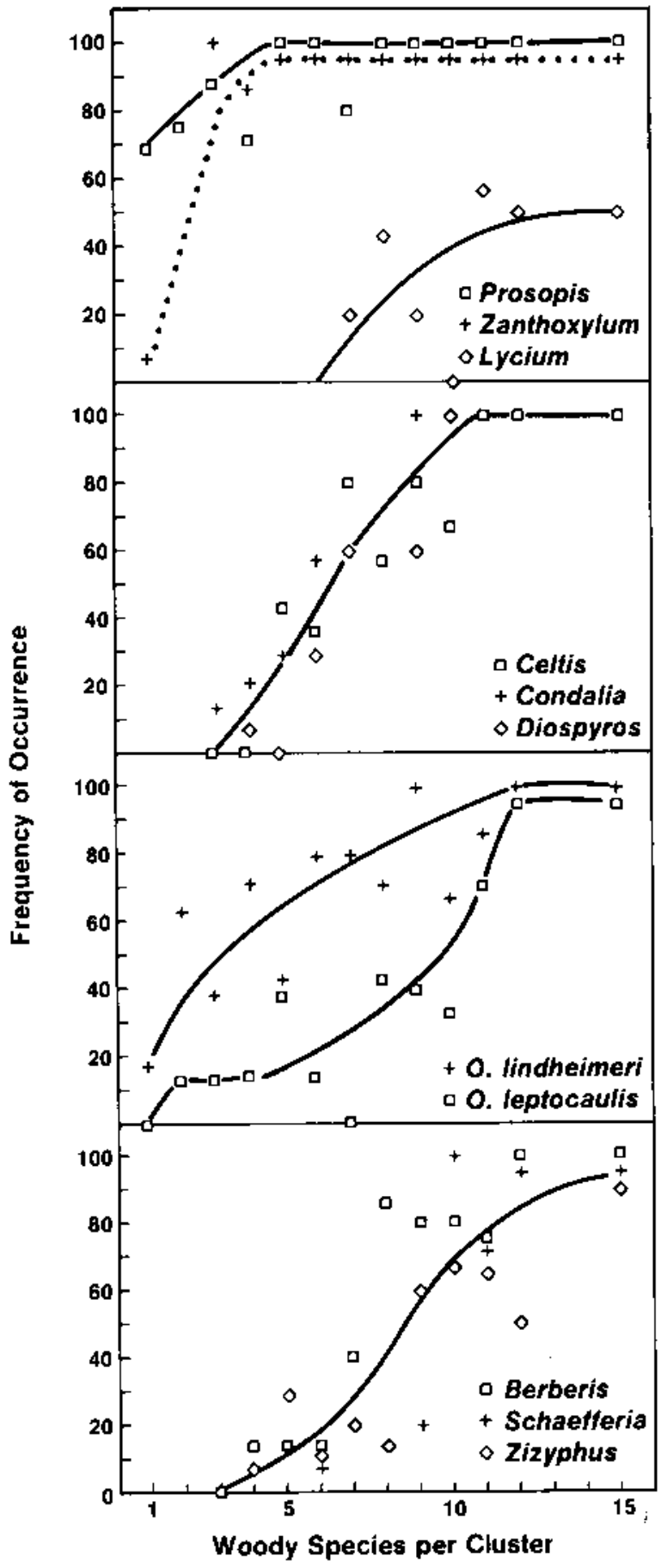

FIG. 3. Frequency of occurrence of woody species in clusters at varying stages of development. In cases where Prosopis was absent from clusters the remains of dead individuals were usually found. Curves were hand fitted.

in a given direction (mean $\pm \mathrm{SE}$ ) ranged from $0.88 \pm$ 0.05 to $1.16 \pm 0.05$ (Eq. 1). Deviations from unity in any one direction were not adequate to infer departure from circularity. The canopy area of combined understory shrubs ( $C A$, in square metres) increased expo- nentially with Prosopis basal diameter ( $B D$, in centimetres):

$$
\begin{gathered}
C A=\exp [-0.12+0 .\{7(B D)] \\
\left(R^{2}=0.72 ; P<.001\right)
\end{gathered}
$$

\section{Gradient analysis}

The number of woody species occurring in each intensively sampled cluster was plotted at the coordinates generated by ordinating total canopy cover of woody species in clusters (Fig. 5). The first axis appeared to represent a temporal cluster development gradient. Cluster area, species richness, diversity, and basal diameter of the central mesquite plant were all positively and significantly correlated with Axis I scores (Table 2).

Seven groups were subjectively delineated in twodimensional ordination space (Fig. 5). Prosopis was the largest individual, in terms of height, basal area, and canopy area in each group. Group I was characterized by lone Prosopis plants, whereas clusters in Group II were Prosopis plants with Opuntia lindheimeri in their understory. Group III clusters, which contained 3-5 woody species, were unique in containing an abundance of Colubrina texensis, a small fruiticose shrub. Clusters in Group IV contained two or three species. Each of the three-species clusters was composed of Prosopis, O. lindheimeri, and Z. fagara; the two-species assemblages were Prosopis plants with one of two suffrutescent shrubs, Lantana macropoda or Salvia baltoteaflora. Group V generally had 4-6 woody species per cluster, while clusters in Group VI and VII were characterized by $9-12$ and 12-15 species, respectively. Generally, as species richness increased, so did $\exp \left(H^{\prime}\right)$, evenness, and cluster size (Table 3). Species dominance of the seven groups in Fig. 5 was determined by computing mean total canopy area of large (basal diameter $\geq 4 \mathrm{~cm}$ ) arborescent individuals (Fig.

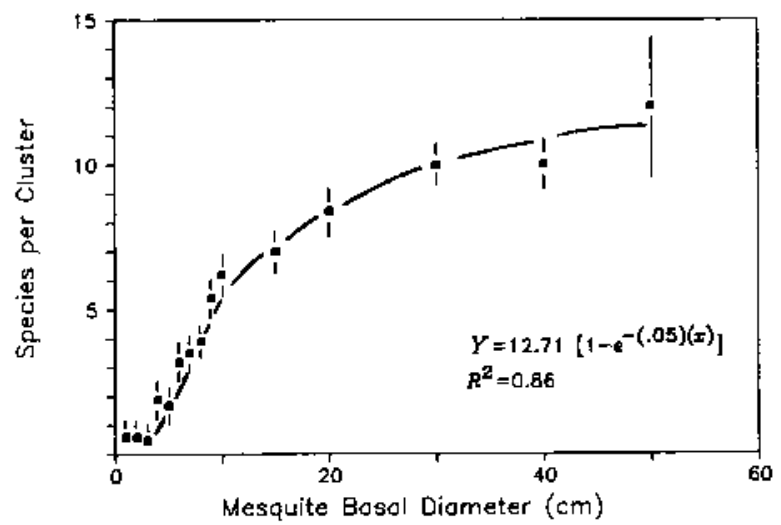

Fig. 4. Relationship between the number of woody species per cluster and the size of the largest (and usually only) Prosopis plant in the cluster. Means ( $\pm \mathrm{SE}$ ) for discrete size classes are plotted for clarity. A nonlinear regression (Eq. 8) of the continuous data yielded $R^{2}=0.86(P<.001 ; N=211)$. 
Woody Species per Cluster

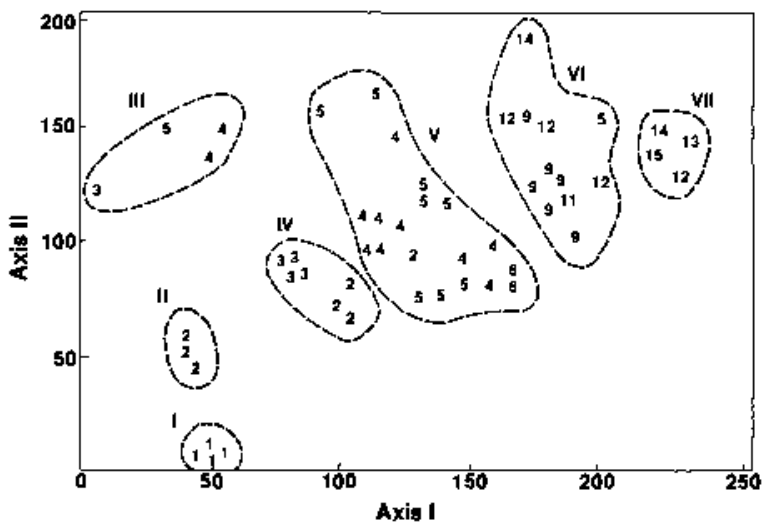

FIG. 5. Distribution of shrub clusters $(N=56)$ on the first two axes of DECORANA. Cluster ordination scores were generated based on transformed total canopy areas of species in each cluster. In this plot, the numbers of species per cluster was plotted at the sample coordinates generated by the ordinated cover values. Axes I and II accounted for 49.8 and $22.1 \%$ of the variance, respectively. Dashed lines grouping samples were derived subjectively. Characteristics of each group are given in Tables 2 and 3 and Figs. 6 and 7.

6). The mean canopy area of the central mesquite plant increased exponentially from Group I to VII and the number of individuals of other woody species in the cluster with basal diameters $\geq 4 \mathrm{~cm}$ also increased.

Seedlings and saplings of Prosopis, which occurred in bigh densities in the herbaceous interspaces, were absent from clusters. In terms of density, the seedling, sapling, and arborescent size classes in well-developed clusters were dominated by Zanthoxylum. followed by Diospyros, Celtis, and Condalia (Fig. 7). Densities of these woody species in clusters were much greater than those in the grassland interspaces (Table 1). Moreover, Celtis, Condalia, and most other woody species occurring in clusters were not encountered in herbaceous interspaces. Size and abundance of most species increased with cluster development (Figs. 6 and 7) for all species except Prosopis. With the exception of Prosopis, the size class structure (high densities of small individuals) and trends in total density of other populations suggest each species will maintain or increase its importance in cluster structure. Condalia and Berberis may be phasing out of Group VII clusters, however (Fig. 7).

\section{Vegetation structure of ephemeral drainages}

A total of 19 woody species were encountered in the continuous canopy wooded drainages surrounding the two-phase portion of the landscape. Prosopis, Zanthoxylum, and Celtis dominated the upper stratum of the wooded zones (Table 4). Diospyros and Condalia were important subordinates. Of those species dominating the upper two strata, only Zanthoxylum, Dios-
TABLE 2. Summary of the relationship between DECORANA scores on Axis I (Fig. 5) and cluster area, diversity $\left(\exp \left[H^{\prime}\right]\right)$, species richness, and diameter of the central mesquite plant. Each variable was positively and significantly $(P<.01)$ correlated with Axis I scores.

\begin{tabular}{lcc}
\hline \multicolumn{1}{c}{ Variable } & Relationship & $R^{2}$ \\
\hline Cluster area & Sigmoid & 0.49 \\
Diversity & Linear & 0.55 \\
Richness & Sigmoid & 0.66 \\
Mesquite size & Sigmoid & 0.59 \\
\hline
\end{tabular}

pyros, and Aloysia were well represented in the smallest size class. Celtis, Condalia, and Berberis were poorly represented in the lower stratum relative to higher strata. Small mesquite plants occurred in the drainages, but many appeared to be vegetative stump sprouts rather than seedlings. As was observed in upland clusters, juvenile mesquite plants were rarely found beneath adults. Their occurrence was primarily confined to canopy gaps. All but two species in the wooded ephemeral drainages (Aloysia gratissima and Yucca treculeana) were also encountered in the upland clusters. Species such as Bumelia, Ephedra, and Lycium occurred only in upland clusters at advanced stages of development. Species composition and relative dominance in the ephemeral drainages (Table 4) was similar to that of clusters at advanced stages of development (Fig. 6).

\section{Rate and dynamics of cluster development}

The proportion of the landscape characterized by the two-phase pattern changed significantly $(P=.014)$ between 1941 and 1983. The areal extent of the twophase pattern increased an average $( \pm \mathrm{SE})$ of $6 \pm 1 \%$ between 1941 and 1960 , resulting from fragmentation of the continuous canopy woody border. By 1983 , however, mean size $( \pm \mathrm{SE})$ of the two-phase area had declined $22 \pm 5 \%$ relative to 1941 . This apparent shrinkage resulted from clusters on the periphery of

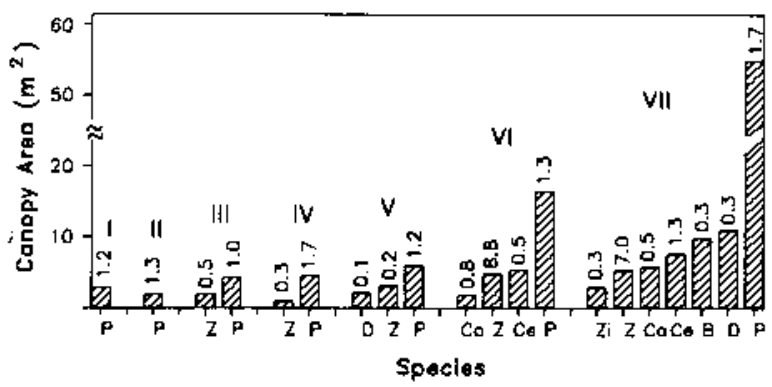

FIG. 6. Woody plants dominating groups of clusters delineated in Fig. 5. Data show mean canopy area per plant of individuals with basal diameters $\geq 4 \mathrm{~cm}$. The numbers above columns are the mean number of individuals per cluster with basal diameters $\geq 4 \mathrm{~cm}$; Roman numerals represent ordination groups. Species codes: $\mathrm{P}=$ Prosopis glandulosa; $\mathrm{Z}=$ Zanthoxylum fagara; $\mathrm{D}=$ Diospyros texana; $\mathrm{Co}=$ Condalia obovata $\mathrm{Ce}=$ Celtis pallida; $\mathrm{Zi}=$ Zizyphus obtusifolia; $\mathrm{B}=$ Berberis trifoliolata. 
TABLE 3. Characteristics of shrub clusters qualitatively grouped according to positioning in the first two axes of DECORANA

(Fig. 5). Where variability estimates are given, data are means $\pm \mathrm{SE}$.

\begin{tabular}{|c|c|c|c|c|c|c|c|c|}
\hline Group* & $\begin{array}{l}\text { Number } \\
\text { of } \\
\text { clusters } \\
\text { sampled }\end{array}$ & $\begin{array}{l}\text { Woody species } \\
\text { per cluster }\end{array}$ & $\begin{array}{l}\text { Total num- } \\
\text { ber of woody } \\
\text { species with } \\
\text { basal diame- } \\
\text { ter }>4 \mathrm{~cm}\end{array}$ & $\begin{array}{l}\text { No. woody } \\
\text { species per } \\
\text { cluster with } \\
\text { basal diameter } \\
>4 \mathrm{~cm}\end{array}$ & $\begin{array}{c}\text { Mean } \\
\text { diversity } \\
\left(\exp \left[H^{\prime}\right]\right)\end{array}$ & $\begin{array}{l}\text { Mean } \\
\text { evenness } \\
(E)\end{array}$ & $\begin{array}{l}\text { Prosopis } \\
\text { plants per } \\
\text { cluster }\end{array}$ & $\begin{array}{c}\text { Cluster size } \\
\qquad\left(\mathrm{m}^{2}\right)\end{array}$ \\
\hline I & 6 & $1.0 \pm 0$ & 1 & $0.5 \pm 0.2$ & 1.0 & $\ldots$ & $1.2 \pm 0.2$ & $1.7 \pm 0.7$ \\
\hline II & 3 & $2.0 \pm 0$ & 1 & $0.7 \pm 0.4$ & 1.7 & 0.17 & $1.3 \pm 0.4$ & $1.8 \pm 0.2$ \\
\hline III & 4 & $4.0 \pm 0.5$ & 2 & $1.3 \pm 0.6$ & 3.2 & 0.41 & $1.0 \pm 0.0$ & $4.8 \pm 1.7$ \\
\hline IV & 7 & $2.6 \pm 0.3$ & 2 & $1.3 \pm 0.3$ & 1.9 & 0.65 & $1.7 \pm 0.8$ & $4.2 \pm 0.4$ \\
\hline $\mathrm{V}$ & 20 & $4.5 \pm 0.2$ & 3 & $1.1 \pm 0.1$ & 2.5 & 0.83 & $1.2 \pm 0.1$ & $5.2 \pm 0.6$ \\
\hline VI & 12 & $9.4 \pm 1.0$ & 8 & $2.3 \pm 0.1$ & 3.9 & 0.81 & $1.3 \pm 0.3$ & $26.7 \pm 5.8$ \\
\hline VII & 4 & $13.5 \pm 0.7$ & 8 & $4.2 \pm 0.9$ & 4.3 & 0.88 & $1.7 \pm 0.3$ & $56.0 \pm 5.7$ \\
\hline
\end{tabular}

* See Figs. 5 and 6.
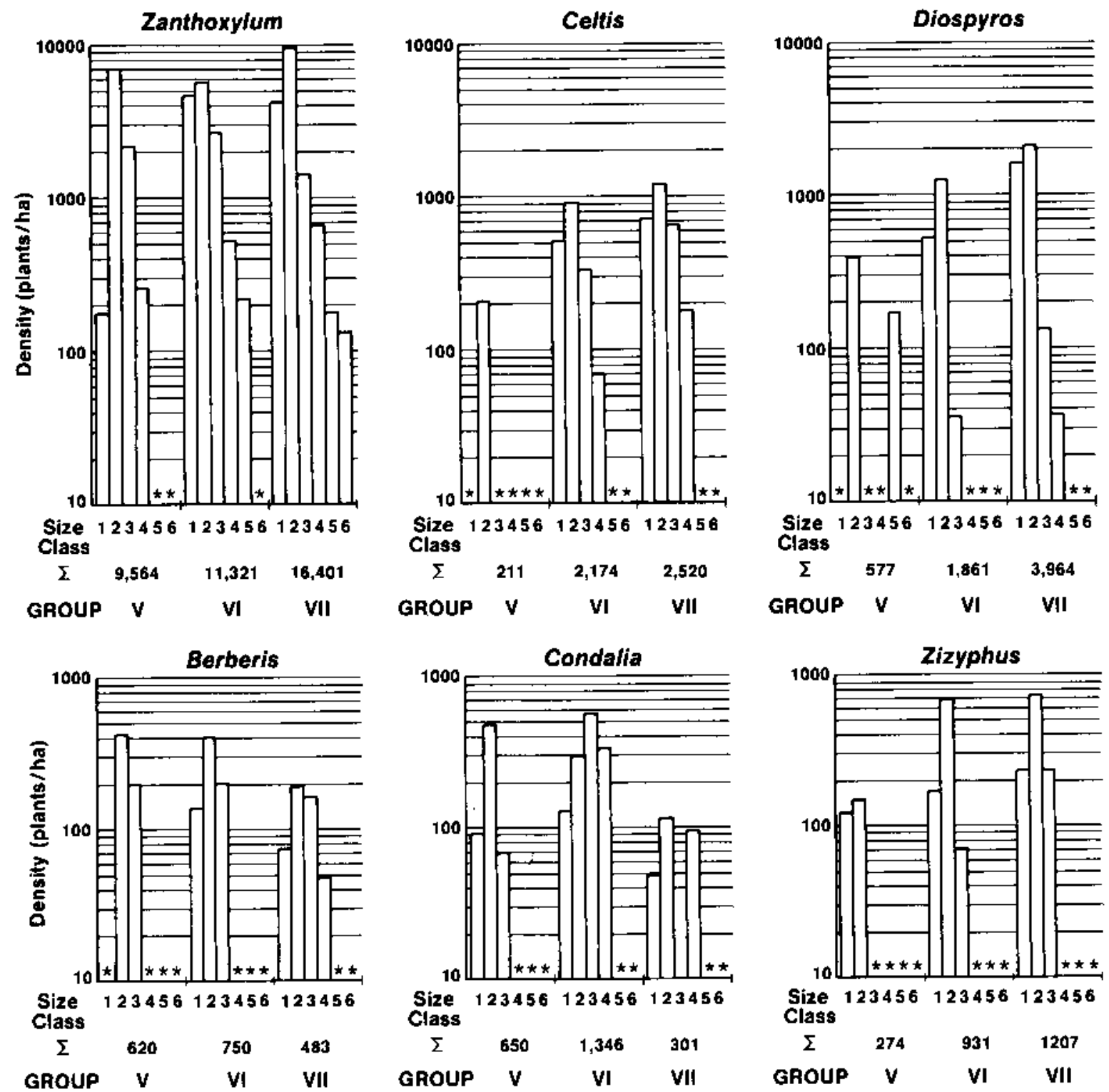

Fra. 7. Mean density of basal diameter size classes in clusters representing ordination Groups V, VI, and VII for six species. The summation line ( 2 ) of abscissa gives mean total density (plants/ha) per cluster. The basal diameter size class codes are: $1=<0.5 \mathrm{~cm} ; 2=0.5-2 \mathrm{~cm} ; 3=2-5 \mathrm{~cm} ; 4=5-8 \mathrm{~cm} ; 5=8-11 \mathrm{~cm} ; 6=>11 \mathrm{~cm}$. Asterisk (*) denotes size classes absent from clusters. 
TABLE 4. Frequency and density of selected woody plants in continuous cover wooded drainages surrounding the area of two-phase patterning. Results, presented for three height strata, were obtained using the point-centered quarter technique $(N=100$ points per stratum). A total of 19 species were encountered.

\begin{tabular}{|c|c|c|c|c|c|c|}
\hline \multirow[b]{3}{*}{ Species } & \multicolumn{6}{|c|}{ Plant height class (m) } \\
\hline & \multicolumn{2}{|c|}{$<1$} & \multicolumn{2}{|c|}{$1-2$} & \multicolumn{2}{|c|}{$>2$} \\
\hline & $\begin{array}{l}\text { Frequency } \\
(\%)\end{array}$ & $\begin{array}{l}\text { Density } \\
\text { (no./ha) }\end{array}$ & $\begin{array}{c}\text { Frequency } \\
(\%)\end{array}$ & $\begin{array}{l}\text { Density } \\
\text { (no./ha) }\end{array}$ & $\begin{array}{c}\text { Frequency } \\
(\%)\end{array}$ & $\begin{array}{l}\text { Density } \\
\text { (no./ha) }\end{array}$ \\
\hline \multicolumn{7}{|l|}{ Arborescents } \\
\hline $\begin{array}{l}\text { Prosopis glandulosa } \\
\text { Zanthoxylum fagara } \\
\text { Celtis pallida } \\
\text { Condalia obovata } \\
\text { Diospyros texana } \\
\text { Acacia farnesiana } \\
\text { Bumelia spp. }\end{array}$ & $\begin{array}{r}12 \\
71 \\
10 \\
4 \\
29 \\
0 \\
1\end{array}$ & $\begin{array}{r}324 \\
2388 \\
191 \\
76 \\
707 \\
0 \\
19\end{array}$ & $\begin{array}{r}15 \\
60 \\
34 \\
32 \\
29 \\
1 \\
1\end{array}$ & $\begin{array}{r}145 \\
523 \\
301 \\
289 \\
288 \\
7 \\
7\end{array}$ & $\begin{array}{l}63 \\
69 \\
57 \\
28 \\
22 \\
13 \\
3\end{array}$ & $\begin{array}{r}295 \\
318 \\
283 \\
97 \\
106 \\
37 \\
9\end{array}$ \\
\hline \multicolumn{7}{|l|}{ Shrubs } \\
\hline $\begin{array}{l}\text { Aloysia gratissima } \\
\text { Opuntia lindheimeri } \\
\text { Colubrina texensis } \\
\text { Schaefferia cuneifolia } \\
\text { Salvia ballotaeflora } \\
\text { Zizyphus obtusifolia } \\
\text { Lycium berlandieri } \\
\text { Berberis trifoliolata }\end{array}$ & $\begin{array}{r}52 \\
27 \\
14 \\
10 \\
9 \\
6 \\
9 \\
0\end{array}$ & $\begin{array}{r}1777 \\
803 \\
477 \\
229 \\
267 \\
133 \\
171 \\
0\end{array}$ & $\begin{array}{r}39 \\
21 \\
14 \\
11 \\
8 \\
11 \\
4 \\
6\end{array}$ & $\begin{array}{r}412 \\
179 \\
105 \\
85 \\
72 \\
85 \\
26 \\
39\end{array}$ & $\begin{array}{l}\cdots \\
\cdots \\
\cdots \\
\cdots \\
\cdots \\
\cdots \\
\cdots \\
\cdots\end{array}$ & $\begin{array}{l}\cdots \\
\cdots \\
\cdots \\
\cdots \\
\cdots \\
\cdots \\
\cdots\end{array}$ \\
\hline
\end{tabular}

the two-phase zone coalescing and merging into the surrounding woodland zones.

Woody plant cover also changed significantly over time within portions of the landscape characterized by the two-phase vegetation pattern (Fig. 8A). Percent coverage of woody plants, comparable on the three sites in 1941, had increased significantly by 1983 . Averaged over sites, woody cover within the two-phase area was 13.0, 13.6, and $23.3 \%$ for 1941, 1960, and 1983 , respectively.

When woody plant cover changes resulting from border encroachment were combined with those changes observed within the two-phase zone, the result was a net increase in area occupied by woody plants of 30 , 16 , and $24 \%$ on S1, S2, and S3, respectively, over the 42-yr period (Fig. 8B). Averaged over the three sites, areal coverage was comparable in 1941 and 1960 (12.6 vs. $7.9 \%$, respectively). By 1983 mean coverage of woody plants had increased $(P<.01)$ to $36.4 \%$. Border encroachment and changes within the two-phase zone contributed equally to this overall increase in cover (49 vs. $51 \%$, respectively).

The density of clusters and point locations within the two-phase area also changed over time. Cluster densities on S1 ( 3.7 clusters/ha) and S2 (3.7 clusters/ ha) were twice that of S3 (L.8 clusters/ha) in 1941 . Cluster density on each of these sites had decreased to 2.L and 2.8 clusters/ha, respectively, by 1960 . By 1983 densities had returned to levels comparable to or slightly greater than those of 1941 . S3, which began with a low cluster density in 1941, changed little through 1960. However, density increased $42 \%$ to 2.7 clusters/ha between 1960 and 1983. Point locations represented the smallest recognizable unit of woody vegetation distinguishable on the aerial photographs. Their densities fluctuated on each of the landscapes in a fashion similar to that of clusters. Mean ( \pm SE) point location densities were $21.1 \pm 4.3$ points/ha in 1941 . Point densities on each site had significantly decreased (mean \pm SE $=$ $16.0 \pm 3.6$ ) by 1960 . Their densities subsequently increased to $26.3 \pm 4.2$ points/ha by 1983 . When sites were pooled, changes in density over time were significant for point locations only.

Kolmogorov-Smimov analysis of the cumulative distribution functions (CDF) indicated size distributions in 1960 and 1983 had shifted to significantly $(P=$ .007) larger clusters (Fig. 9). Although there was an increase in the number of clusters in all but one size class between 1960 and 1983, the CDF's for these two dates did not differ $(P=.16)$. The main effect of site and date each were significant $(P<.002)$ and there was no interaction $(P=.35)$. Mean cluster size tended to be largest on $\mathrm{S} 3\left(687 \pm 70 \mathrm{~m}^{2}\right.$ in $1941 ; 838 \pm 90$ $\mathrm{m}^{2}$ in 1983) and smallest on $\mathrm{S} 2(368 \pm 39$ and $684 \pm$ $68 \mathrm{~m}^{2}$ in 1941 and 1983 , respectively). Greatest increases in cluster size occurred between 1941 and 1960 . Mean ( \pm SE) cluster size averaged across sites was $494 \pm$ $; 79,656 \pm 49$, and $717 \pm 61 \mathrm{~m}^{2}$ in $194 \mathrm{l}, 1960$, and 1983, respectively.

An increase in cluster size over time could result from both coalescence and expansion of individual clusters. Because we could not precisely register overlays of different years we could not completely quantify the degree to which each of these factors was operational across the landscape. However, we were able to identify uniquely a total of 29 individual clusters and estimate their growth rates and patterns of development over the 42 -yr period. Changes in size, absolute $(G R)$, and relative ( $R G R)$ growth rates were observed among size classes (Table 5). For each variable, date, 


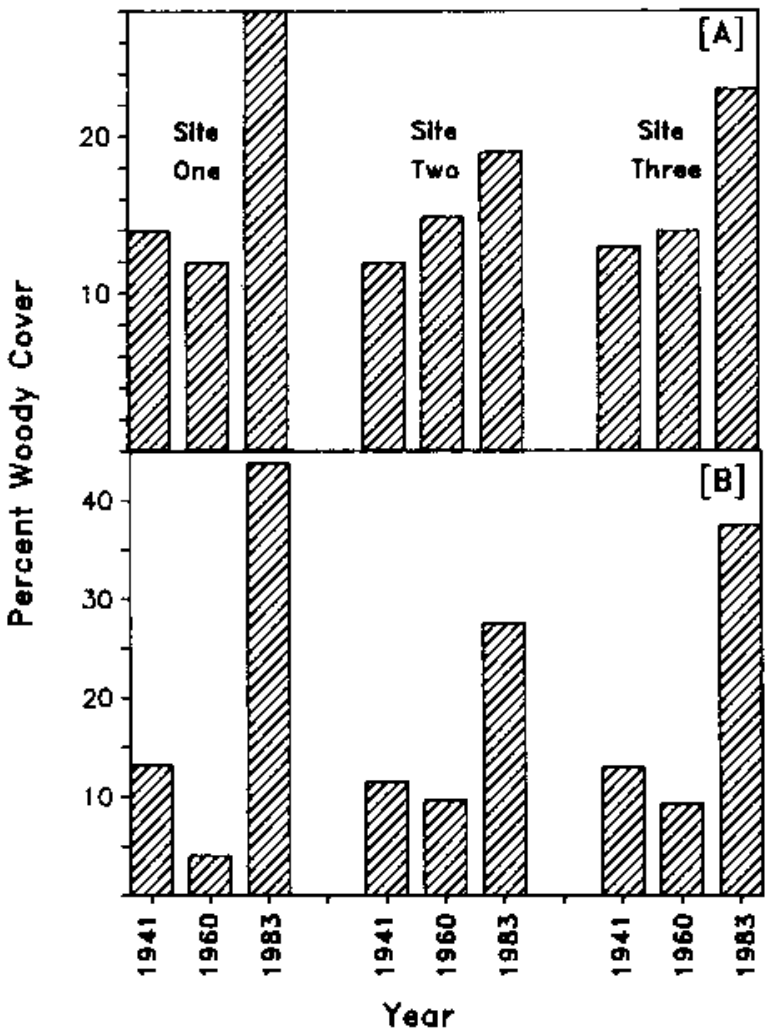

Fta. 8. (A) Changes in percent woody plant cover within that portion of the landscape characterized by the two-phase pattern, sites 1, 2, and 3. (B) Net change in total woody plant coverage (Eq. 7) resulting from border encroachment and cluster development within the two-phase pattern.

size class, and their interaction were significant; site and other two-way interactions were not. Small clusters $\left(<100 \mathrm{~m}^{2}\right)$ had the highest $R G R$ in each time period, with the $R G R$ in the $1960-1983$ period $60 \%$ higher than that of the 1941-1960 period. The $R G R$ among larger clusters were comparable and an order of magnitude lower than those of the smallest size class. Mean growth rates were positive in all size classes during the drought period, except among clusters $>1000 \mathrm{~m}^{2}$. The mean absolute growth rates observed for clusters represent radial increases of $1.8-3.2 \mathrm{~m} / \mathrm{yr}$.

During the period encompassing the drought (1941$1960),>34 \%$ of the identified clusters decreased in area vs. $17 \%$ in the subsequent time period (1960-1983). of the 29 clusters identified, five had formed from the coalescence of point locations between 1941 and 1960 . During the same period, four small clusters fragmented into eight point locations while two larger clusters each fragmented into a pair of smaller clusters. In the time period following the drought, eight point locations coalesced to form four small clusters. On two occasions, two large clusters merged to form one. No fragmentation was observed. Thus, over the $42-y r$ period, 15 of the 29 clusters followed coalesced with other clusters. Numerous portions of the upland landscapes in
Fig. 1 were characterized by woody assemblages representing the merger of 4-10 clusters organized beneath mesquite.

\section{DISCUSSLON \\ Landscape development}

The development of woody assemblages in the Rio Grande Plains appears to fit the facilitation model of Connell and Slatyer (1977). Mesquite colonized grassland sites and served as the nucleus of cluster organization (e.g., Yarranton and Morrison 1974), apparently acting as a nurse plant that facilitated the ingress and establishment of additional woody species otherwise restricted to other habitats. The result was a landscape composed of chronosequences of discrete woody plant assemblages (Fig. 10) dispersed throughout a continuous grassy matrix.

Woody plant cover increased significantly (16-36\%) between 1941 and 1983 on this site, which had a history of heavy grazing since the late 1800 's. Changes were the combined result of clusters merging into adjacent woodlands, an increase in the size of clusters (Table 5, Fig. 9), and an increased density of point locations (clusters $<5 \mathrm{~m}^{2}$ ). Increases in woody plant cover associated with border encroachment were comparable to those attributed to cluster development within the two-phase zone.

Although there was a net increase in woody plant cover over the 42-yr period, the development of woody assemblages was clearly punctuated by variations in precipitation. A decline in total woody plant cover occurred on two of the three sites between 1941 and 1960 (Fig. 8B), a period characterized by a major

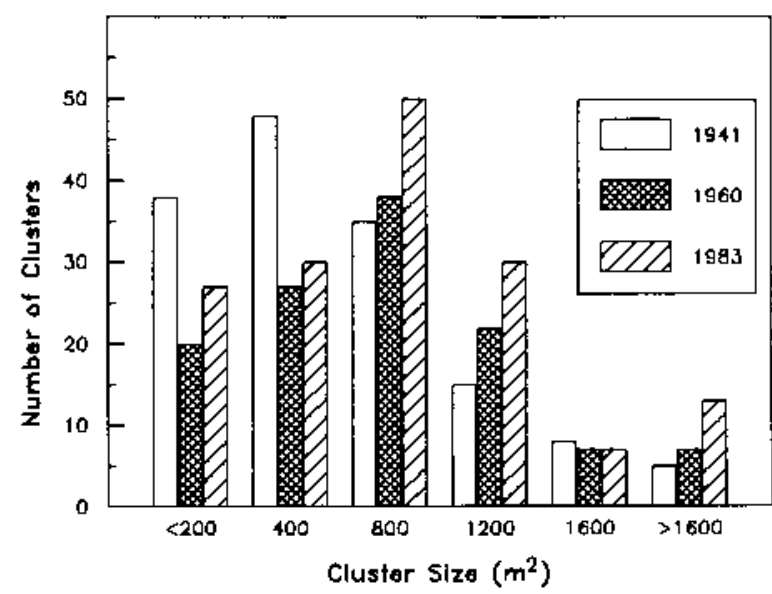

Fig. 9. Changes in the size class distribution of clusters within the two-phase zone over time. Point locations (clusters $<5 \mathrm{~m}^{2}$ ) not included. Kolmogorov-Smimov analysis of cumulative distribution functions (CDF) indicated that distributions in 1960 and 1983 had shifted significantly toward larger size classes relative to $194 \mathrm{~L}$. However, $C D F^{\prime} \mathrm{s}$ for 1960 and 1983 differed only at $P=, 16$. Count data shown here are from all three sites combined. 
drought (Norwine 1978). Coverage on the third site remained static. Decreases in cover were the result of gap formation and cluster fragmentation along the border of the two-phase zone and a decreased density of point locations. The decline in point density across all sites from a mean of $24 /$ ha to $16 /$ ha during this period presumably reflected mortality among small $\left(<5 \mathrm{~m}^{2}\right)$ clusters. Mortality may have been underestimated, since fragmentation of small clusters observed during the drought period would have inflated the 1960 density estimate. With the exception of clusters $>1000 \mathrm{~m}^{2}$, mean growth rates during this time period were positive but low. The marked shift in size class distribution between 1941 and 1983 (Fig. 9) appears to have been the result of the high $R G R$ among small clusters (Table 5). The distribution of cluster size classes did not shift significantly between 1960 and 1983 , even though clusters increased in size and had consistently higher growth rates during this period.

Carter ( 1964 ) made some qualitative observations on the vegetation in counties near our study site during and after the drought period. He reported that mortality of mesquite, the nucleus of cluster organization, ranged from 50 to $75 \%$, and that subordinate shrubs died back to ground level but often resprouted. He further noted that most mortality was not evident until the final $2 \mathrm{yr}$ of the drought. His observations on the loss of Prosopis and the subsequent recovery of subordinate woody species help explain the decrease in size in 10 of the 29 clusters followed during this time period, the decrease in point densities, and the subsequent cluster expansion observed during the pluvial period.

Between 1960 and 1983 , substantial increases in woody plant cover occurred (Fig. 8). Rapid increases in woody plant cover and density following prolonged drought have also been observed by Buffington and Herbel (1965) and Herbel et al. (1972), and support hypotheses presented by Neilson (1986) pertaining to weather variability, vegetation change, and inertia. Following the drought period, coalescence of clusters into borders led to a decrease in the areal extent of the two-phase pattern, while woody plant cover increased within the two-phase zone (Fig. 8A). Although growth rates of the smallest and largest clusters during this period were higher than those of the same clusters during the drought period, growth rates were not significantly different among intermediate size classes (Table 5). Edaphic heterogeneity and proximity to other clusters may have had a strong bearing on rates of cluster development. However, we could not partition variance associated with the latter variable with our small sample sizes.

Part of the increase in woody cover within the twophase zone between 1960 and 1983 was the result of an increase in mean point densities from $16 /$ ha to $26 /$ ha. This increase, which occurred during a period when cluster fragmentation was nil and numerous points were merging to form clusters, represents the recruitment of new clusters onto the site. Such clusters, with a canopy area of 4-5 $\mathrm{m}^{2}$, would typically have 3-4 woody species (Eq. 9): a lone Prosopis plant with a basal diameter of $\approx 7 \mathrm{~cm}$, Opuntia lindheimeri, and Zanthoxylum fagara (Fig. 3). Either Condalia obovata, Diospyros texana, or Celtis pallida would be the fourth species. Appearance of these small clusters between 1960 and 1983 suggests that the Prosopis plant forming their nucleus was present in the previous time period and survived the drought. This inference was substantiated by Carter (1964), who reported that mesquite plants with stem diameters of $2-6 \mathrm{~cm}$ withstood the drought on all sites examined.

Many landscapes in the region presently characterized by continuous woody plant cover appear to have developed from the coalescence of clusters organized around mesquite. As clusters on the two-phase site developed, they became increasingly similar to adjacent closed-canopy woody assemblages in terms of species composition, dominance, and size class structure (Figs. 6 and 7; Table 4). On the two-phase landscape, $50 \%$ of the clusters were within $5 \mathrm{~m}$ of another and $95 \%$ were within $15 \mathrm{~m}$ of another. The size class distribution of clusters (Fig. 2) suggests that most should continue to grow and enlarge (Table 5, Fig. 9). In addition, herbaceous clearings between clusters contained high densities of Prosopis seedlings and saplings (Table L). Coalescence will become increasingly probable on the remaining two-phase portion of the landscape as new clusters are initiated and existing clusters continue to enlarge. We therefore suggest the two-phase pattern represents an intermediate stage in the physiognomic conversion of a grassland or savanna to woodland. Woodlands on nearby, more mesic, ephemeral drainages (Fig. 1) appear to represent sites where this process has already occurred.

\section{Cluster development}

$R G R$ of clusters $<100 \mathrm{~m}^{2}$ in canopy area were an order of magnitude greater than that of larger clusters (Table 5). This was presumed to reflect rapid early canopy development of the mesquite plant forming the center of the cluster (Fig. 6). At later stages, cluster expansion was primarily from recruitment and growth of individuals of other woody species around the perimeter of the mesquite canopy (Eq. 10). Subordinate species in clusters were smaller in stature with smaller canopies than mesquite. In addition, many were evergreens with low intrinsic growth rates. Thus, the decrease in $R G R$ with increasing cluster size appears reasonable.

Opuntia lindheimeri and Zanthoxylum fagara were typically the first woody species to appear beneath mesquite plants invading the upland grasslands. These were followed, with roughly equal probability, by Celtis pallida, Condalia obovata, and Diospyros texana. Shrubs such as Zizyphus obtusifolia, Berberis trifoliolata, 
TABLE 5. Mean ( $\pm \mathrm{SE}$ ) size, relative ( $R G R ; \mathrm{Eq} .1$ ) and absolute ( $G R ; \mathrm{Eq}$. 2) growth rates of 29 clusters between $194 \mathrm{I}$ and 1983. Site and the date $\times$ site interaction were not significant for cluster size, $R G R$, or $G R$, so the three sites were pooled. For each variable, means within a row followed by the same letter were not significantly different at $P<.05$ (Tukey's $Q$ procedure)

\begin{tabular}{|c|c|c|c|c|c|}
\hline \multirow{2}{*}{$\begin{array}{c}\text { Size } \\
\text { class }\left(\mathrm{m}^{2}\right)^{*}\end{array}$} & \multicolumn{3}{|c|}{ Cluster size $\left(\mathrm{m}^{2}\right)$} & \multicolumn{2}{|c|}{$R G R\left(\mathrm{~m}^{2} \cdot \mathrm{m}^{-2} \cdot \mathrm{y}^{-1}\right) \dagger$} \\
\hline & 1941 & 1960 & 1983 & $1941-1960$ & $1960-1983$ \\
\hline $\begin{array}{c}<100 \\
100-400 \\
400-1000 \\
>1000\end{array}$ & $\begin{array}{c}40 \pm 9 \mathrm{a} \\
302 \pm 25 \mathrm{a} \\
665 \pm 54 \mathrm{a} \\
1916 \pm 217 \mathrm{a}\end{array}$ & $\begin{array}{l}407 \pm 121 \mathrm{~b} \\
481 \pm 103 \mathrm{a} \\
775 \pm 219 \mathrm{a} \\
836 \pm 398 \mathrm{~b}\end{array}$ & $\begin{array}{r}675 \pm 130 \mathrm{c} \\
974 \pm 143 \mathrm{~b} \\
1665 \pm 534 \mathrm{~b} \\
1565 \pm 204 \mathrm{a}\end{array}$ & $\begin{array}{r}0.10 \pm 0.02 \mathrm{a} \\
0.01 \pm 0.03 \mathrm{a} \\
0.01 \pm 0.03 \mathrm{a} \\
-0.08 \pm 0.06 \mathrm{a}\end{array}$ & $\begin{array}{l}0.16 \pm 0.01 \mathrm{~b} \\
0.03 \pm 0.01 \mathrm{a} \\
0.02 \pm 0.01 \mathrm{a} \\
0.01 \pm 0.01 \mathrm{~b}\end{array}$ \\
\hline
\end{tabular}

* Clusters were placed in one of four classes based upon their size in 1941. Means sizes reflect subsequent changes to clusters grouped according to their classification in 1941.

† In calculating growth rates, clusters were assigned to new size class categories in 1960 when appropriate.

Schaefferia cuneifolia, and Lycium berlandieri appeared only at successively later stages of cluster development. With the exception of Opuntia lindheimeri and $O$. leptocaulis, no clear or consistent spatial patterns of plant distribution were apparent within the clusters. When these species occurred in a cluster (Fig. 3), they were consistently restricted to the perimeter (Fig. 10). Although other leguminous aborescents such as Acacia farnesiana occurred on the site (Tables 1 and 4), they played no apparent role in cluster development. This is in contrast to the Acacia schaffneri-Opuntia spp. vegetation mosaics described by Yeaton and Manzanares (1986) in central Mexico.

New woody species were added as clusters developed (Fig. 4), but none were lost (Figs. 3 and 6) except Prosopis, which had died in $\approx 25 \%$ of the clusters and was not being replaced. However, trends in the size class structure and density of the Condalia and Berberis populations suggest these species may eventually be phased out (Fig. 7). A comparison of the vegetation in clusters at advanced stages of development with that of the adjacent continuous canopy woodlands further sug- gests this to be the case. If woody vegetation of the adjacent, more mesic drainages (Table 4) represents a general developmental extension of the clusters on the two-phase portion of the landscape, we would anticipate a gradual loss of Prosopis, Celtis, Condalia, and Berberis. Zanthoxylum and Diospyros would eventually dominate the aborescent strata, while frutescent species such as Aloysia, Colubrina, and Schaefferia would dominate the mid-stratum.

The high correlation $\left(R^{2}=0.64\right)$ between number of woody species and cluster area (Eq. 4) and the low species richness at the $Y$ intercept (2.86) suggest that shrub clusters behave as ecological islands. The slope obtained for the species-area relationship $(z=0.33)$ was island-like and suggests nonequilibria (but see Connor and McCoy 1979). The maximum number of species in a cluster was $15(N=2)$, whereas total number of woody species in the adjacent, monophasic woodlands was 19 . Thus the prediction of nonequilibria seems plausible. Although we do not know ages of woody plants in clusters, a large portion of the species appear to have been added to clusters rather rapidly

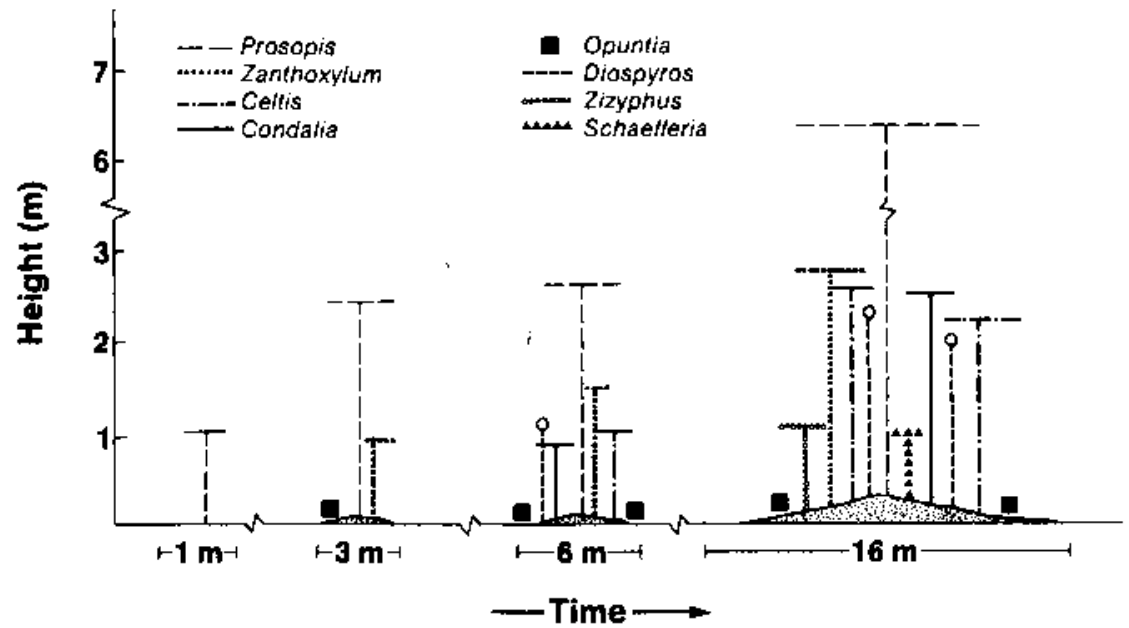

FIG. 10. Diagrammatic illustration of the chronosequential development of shrub clusters on fine Ioamy uplands in the Rio Grande Plains, Texas. These landscapes may be moving from the present two-phase configuration-discrete woody clusters scattered throughout the continuous grassland matrix - toward a monophasic woodland, as new clusters are initiated and existing clusters expand and coalesce. 
Table 5, Continued.

\begin{tabular}{rc}
\hline \multicolumn{2}{c}{$G R\left(\mathrm{~m}^{2} / \mathrm{yr}\right) \dagger$} \\
\hline $1941-1960$ & $1960-1983$ \\
\hline $19.3 \pm 6.4 \mathrm{a}$ & $32.0 \pm 4.9 \mathrm{~b}$ \\
$10.7 \pm 4.8 \mathrm{a}$ & $16.6 \pm 5.9 \mathrm{a}$ \\
$11.8 \pm 9.4 \mathrm{a}$ & $23.8 \pm 10.6 \mathrm{a}$ \\
$-54.8 \pm 13.6 \mathrm{a}$ & $28.2 \pm 22.2 \mathrm{~b}$ \\
\hline
\end{tabular}

(Fig. 4). As clusters developed, species richness, evenness, and diversity increased (Tables 2 and 3 ) and losses of woody species were negligible (Fig. 3). Species appearance sequences in clusters seemed fairly consistent, reflecting differential and sequential dispersal of species to developing clusters and/or changes in the probability of species recruitment associated with edaphic/microclimate modifications presumed to accompany cluster development.

Prosopis was absent from $17 \%$ of the clusters and had died in another $24 \%$ of the clusters. It seems likely that many of the clusters presently without mesquite may have had the plant at one time, although the remains have disappeared. We cannot infer from these data how loss of Prosopis affected cluster dynamics or development. Because we did not intensively sample clusters without Prosopis we cannot speculate how loss of the nucleus may have impacted cluster development. Loss of mesquite during early stages of cluster formation may be of major importance, whereas its loss at later stages is probably of less consequence. Based upon the long-term mesquite removal experiment of Klemmedson and Tiedemann (1986) and Tiedemann and Klemmedson (1986), we hypothesize rates of cluster expansion and development would slow following death of Prosopis, mainly because of a decline in soil nitrogen levels.

Causes of Prosopis mortality were likely related to the major drought that occurred in this region in the 1950's (Norwine 1978). The effects of that drought on woody plants in counties near our study site have been qualitatively noted. Plant mortality was apparently high (40-75\%) among Prosopis populations in numerous habitats. Although understory shrubs also died back, they were rarely killed and recovered rapidly via sprouts (Carter 1964). We observed numerous healthy clusters with dead mesquite. If the Prosopis plants in these clusters died during the 1950's drought, there were no obvious signs of cluster deterioration during our 1984 inventory. We infer from such observations that clusters are a persistent feature of these landscapes and that succession is linear from one state (grassland) to another (woodland) and not a cyclic replacement series such as that described by Yeaton (1978) or Pemadasa (1981).
Our results provide inferential evidence in support of Connell and Slatyer's (1977) facilitation model of succession.

\section{Implications for conversion of grasslands to shrublands}

Although the potential natural vegetation of the Rio Grande Plains has been classified as grassland and savanna (e.g., Kuchler 1964), the current woody flora has likely been present in this area throughout the Holocene, perhaps restricted to escarpments, caliche ridges, drainages, and riparian zones. Mesquite, for example, was a part of the Pliocene flora in southern California (Axelrod 1937), and wood of Prosopis spp. has been recovered in southern Texas from archaeological sites dated at 1300 BC (Hester 1980). Johnston (1963) presented evidence that the geographic range of Prosopis glandulosa has changed little in the past $300-500$ yr and suggested that it has merely increased in stature and abundance within its historic ranges. Numerous historical accounts from the early 1800 's describe many landscapes of south Texas as open prairies with woody plants confined to areas adjacent to watercourses (Bogusch 1950, Malin 1953). Palmer (1871), Tharp (1926), and others have suggested the spread of Prosopis has been lateral, from wooded bottoms to upland prairies.

Mesquite is an ideal woody invader of grasslands for several reasons. It produces abundant seed (Fisher et al. 1959), which are long-lived in the soil (Tschirley and Martin 1960). Germination and establishment can occur on a wide range of soil types, having a variety of physical and chemical properties (Ueckert et al. 1979), moisture (Scifres and Brock 1969), and light regimes (Scifres et al. 1973). Its ability to fx nitrogen at the seedling (Bailey 1976) and adult (Shearer et al. 1983) stages of the life cycle would further enhance its ability to invade sites successfully. Mesquite seedlings quickly develop extensive tap and lateral roots (Haas et al. 1973) and are capable of perennation $1 \mathrm{wk}$ after germination (Scifres and Hahn 1971). Survival of 2and 3-yr-old seedlings can exceed $80 \%$ following very hot fires (Wright et al. 1976). Thus, Prosopis glandulosa is an aggressive species not easily eliminated from a site once established.

Given these invasive properties, dispersal rather than establishment limitations may have kept Prosopis densities low on grasslands prior to the introduction of livestock (see Brown and Archer 1987). Thus, mesquite may have been largely restricted to riparian zones, drainages, and escarpments until recent times. Alternatively, native herbivores and granivores such as deer, bison, and rodents may have been disseminating mesquite seeds, but few propagules established in the grasslands. Those that did may have been subsequently eliminated or kept low in stature by recurring fire. With the introduction of cattle, sheep, and horses, all effective vectors of mesquite seed dispersal (Glendening and Paulson 1950, Glendening 1952, Fisher et al. 1959, 
Brown and Archer 1987), Prosopis abundance and stature would subsequently have increased in upland grasslands. Livestock appear to be an especially effective vector of Prosopis seed dispersal in that they transport large numbers of seeds away from parent trees where host-specific seed and seedling predators may exist (e.g., Janzen 1970, Webb and Wilson 1985), scarify them and deposit them in a nutrient-rich media (dung) in areas where herbaceous interference and the probability of fire have been reduced by grazing. As mesquite developed on grazed sites, the structural complexity of the single-stratum grasslands would have increased, attracting avifauna that frequent wooded habitats. Mesquite saplings and trees in grasslands may have then become recruitment foci for the bird-disseminated seeds of woody plants occupying other habitats.

Data from other systems support this hypothesis. For example, high concentrations of bird-dispersed woody plants are commonly observed to occur in linear assemblages under power line poles and along fences in prairies and old fields generally lacking woody vegetation (e.g., Hooper and Bullington 1972). In the Piedmont of New Jersey, McDonnell and Stiles (1983) found that woody plant seed deposition in old fields by birds during secondary succession was low until some woody species became established to provide perches. When they constructed artificial perching structures, woody plant seed input increased by more than an order of magnitude. As the bird-dispersed woody plants matured, they became primary sources of additional propagules while serving as foci for birds carrying other seeds. Fuentes et al. (1986) and Guevara et al. (1986) ascribed a similar importance to birds in the development of woody clusters in Chilean matorral and Mexican rain forest, respectively.

As mentioned previously, clusters were not observed to form in association with Acacia farnesiana, another aborescent legume on the site. Acacia spp. modify soils in ways similar to mesquite (Garcia-Moya and McKell 1970, Bush and van Auken 1986) and serve as facilitators in other systems (e.g., Yeaton and Manzanares 1986). Structurally Prosopis and Acacia differ, however. Relative to mesquite, $A$. farnesiana is more finely and densely branched, with slender, often pendulous twigs having higher densities of smaller thorns. Absence of subordinate shrubs beneath $A$. fornesiana may thus be a consequence of a canopy architecture unattractive to perching birds.

\section{How stable is the present landscape?}

Once established, Prosopis appears to initiate autogenic successional processes that may have changed the physiognomy of landscapes in the Rio Grande Plains from grassland to a woodland. A conceptual model summarizing the hypothesized sequence of events is presented in Fig. 11. As mesquite invades and establishes in herbaceous interspaces (Table 1), new clusters will be formed, expand (Table 5, Fig. 9), and eventually coalesce with other clusters. Our analysis of aerial photography from 194 L 1960, and 1983 supports this contention. Although some of the large clusters were noticeably impacted by the severe drought, all recovered rapidly during the subsequent time period, primarily via vegetative regeneration (Carter 1964). Several smaller clusters fragmented, but, on the average, maintained a positive growth rate. The fragmentation observed was probably the result of gaps formed by the death of the central Prosopis plant. Mortality was high among the smallest detectable woody assemblages (the point locations). However, recruitment in the subsequent pluvial period more than compensated for these losses. Such data indicate that woody clusters will generally persist and continue to develop, albeit in a dynamic fashion. Unless there are pyric or edaphic constraints to additional mesquite establishment and cluster growth, it appears these landscapes will eventually develop a monophasic woodland physiognomy. It is therefore hypothesized this landscape is moving from its present two-phase pattern toward a monophasic woodland configuration similar to that presently occupying more mesic sites.

Alternatively, other factors, perhaps edaphic, may limit future development of woody clusters on these landscapes. For example, ironstone layers in the Venezuelan Llanos keep that area in a savanna physiognomy and prevent its succession to woodlands (San Jose and Farinas 1983). In palm (Copernica spp.) savannas of South America and Africa, woody plants tend to occur in depressions that accumulate fine clays, while in the Brazilian Campos Cerrados variations in phosphorus availability influence woody plant distributions (Walter 1979). Fuentes et al. (1984) described a clumping pattern of shrubs in the Chilean matorral and suggested that clusters merged to form continuous cover anly on very mesic sites. Preliminary data from our site on the Rio Grande Plains in south Texas indicate soils beneath large, coalesced shrub clusters have poorly developed argillic horizons relative to that of smaller clusters and herbaceous interspaces. However, it is not yet clear whether cluster location and development are regulated by edaphic discontinuities, or if woody plants have modified a once homogeneous soil. If the former is the case, the current two-phase pattern may be rather stable.

\section{ACKNOWLEDGMENTS}

We thank Dr. W. H. Blackbum for his active collaboration in the early stages of this research, and Ben Koerth, Jim Mutz, Andy Crane, Rob Flinn, Ken Parker, and Lynn Loomis for help in field data collection. Their many hours of recording and measuring in dense brush amidst ticks, reptiles, thorns, and high temperatures will be difficult for athers to appreciate fully. This study could not have been done without them. David Briske, Scott Collins, Hyrum Johnson, Nick Reid, Osvaldo Sala, and Joe Walker made helpful comments on various portions of the manuscript. The efforts of Ecological Manographs editors and two anonymous reviewers are also appreciated. This research was conducted in connection with 


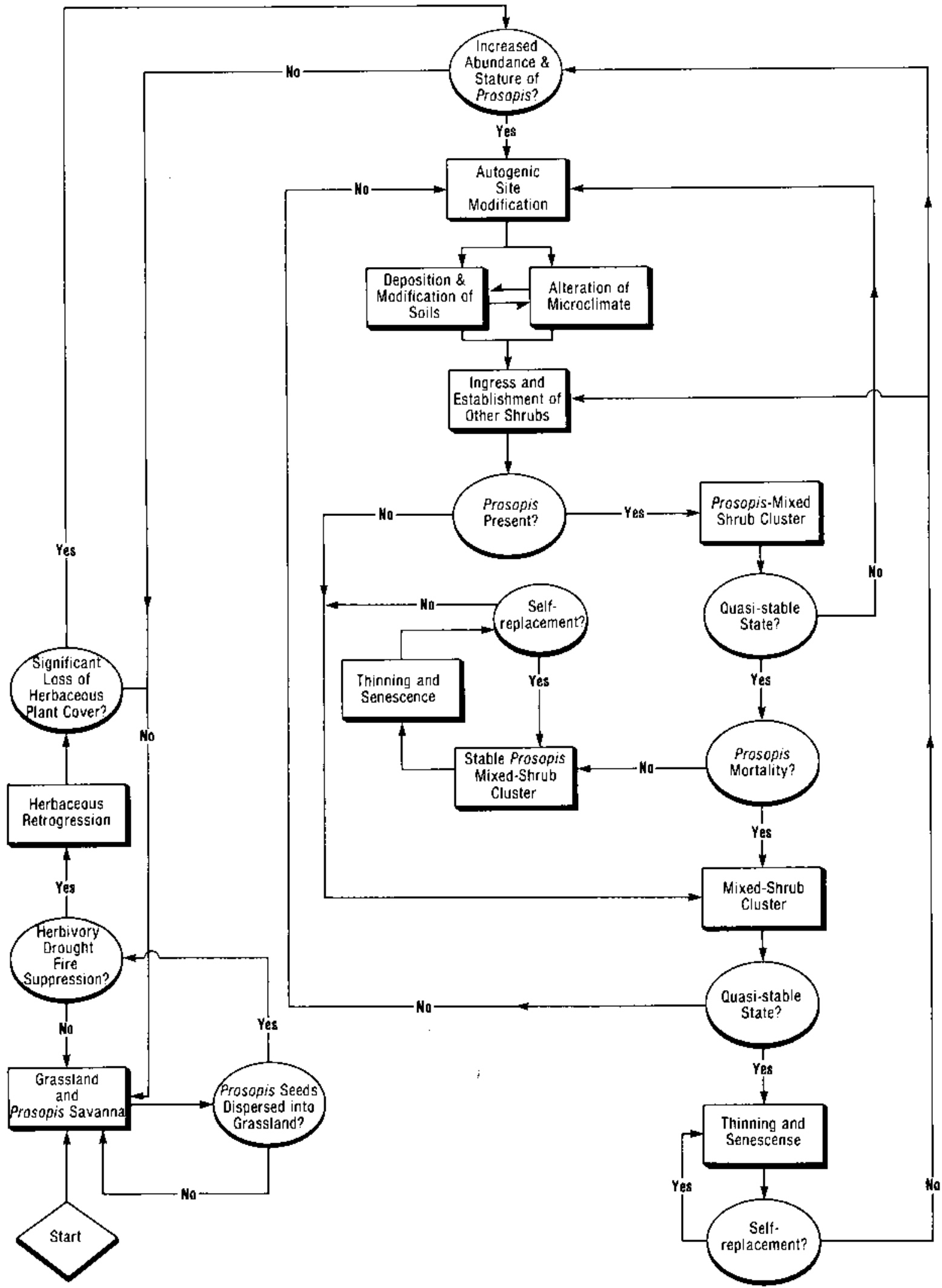

FIG. 11. A conceptual model of grassland to shrubland conversion and woody plant community development on fine loamy uplands in the Ria Grande Plains, Texas. 
projects $\mathrm{H}-6717, \mathrm{H}-1922$, and MS-6131 of the Texas Agricultural Experiment Station and is published with approval of the Director as Manuscript 22188.

\section{Literature CIted}

Alatalo, R. V. 1981. Problems in the measurement of evenness in ecology. Oikos 37:199-204.

Axelrod, D. L. 1937. A Pliocene flora from the Mt. Eden beds, southern California. Carnegie Institute of Washington Publication 476:125-183.

Bailey, A. W. 1976. Nitrogen fixation in honey mesquite seedlings. Journal of Range Management 29:479-481.

Barton, D. C. 1933. Surface fracture system of South Texas. Bulletin of the Association of Petroleum Geologists 17: 1194-1212.

Blackburn, W. H., and P. T. Tueller. 1970. Pinyon and juniper invasion in black sagebrush communities in eastcentral Nevada. Ecology 51:841-848.

Blair, W. F. 1950 . The biotic provinces of Texas. Texas Journal of Science 2:93-1 17

Bogusch, E. R. 1950 . A bibliography on mesquite. Texas Journal of Science 2:528-539.

-_... 1952. Brush invasion on the Rio Grande Plains of Texas. Texas Journal of Science 4:85-91.

Brown, J. R., and S. Archer. 1987. Woody plant seed dispersal and gap formation in a North American subtropical savanna woodland: the role of domestic herbivores. Vegetatio, in press.

Buffington, L. C., and C. H. Herbel. 1965. Vegetational changes on a semidesert grassland range from 1858 to 1963 . Ecological Monographs 35:139-164.

Bush, J. K., and W. O. van Auken. 1986. Changes in nitrogen, carbon and other soil surface properties during succession. Soil Science Society of American Joumal 50:15871601 .

Carter, M. G. 1964. Effects of drouth on mesquite. Journal of Range Management 17:275-276.

Connell, J. H., and R. O. Slatyer. 1977. Mechanisms of succession in natural communities and their role in community stability and organization. American Naturalist 111 : $1119-1144$

Connor, E. F., and E. D. McCoy. 1979. The statistics and biology of the species-area relationship. American Naturalist 113:79 I-833.

Correll, D. S., and M. C. Jahnston. 1979. Manual of the vascular plants of Texas. University of Texas at Dallas, Richardson, Texas, USA

Cottam, G., J. T. Curtis, and B. W. Hale. 1953. Some sampling characteristics of a population of randomly dispersed individuals. Ecology 34:741-757.

Davis, R. B., and R. L. Spicer. 1965. Status of the practice of brush control in the Rio Grande Plain. Texas Parks and Wildlife Department, Austin, Texas, USA.

Emmanuel, W. R.1 H. H. Shugart, and M. Stevenson. 1985. Climatic change and the broad-scale distribution of terrestrial ecosystem complexes. Climatic Change 7:29-43.

Fisher, C. E., C. H. Meadors, R. Behrens, E. D. Robison, P. T. Marion, and H. L. Morton. 1959. Control of mesquite on grazing lands. Texas Agricultural Experiment Station Bulletin 935, Texas A\&M University, College Station, Texas, USA.

Fuentes, E. R., A. J. Hoffman, A. Poiani, and M. C. Alliende. 1986. Vegetation change in large clearings: pattems in the Chilean matorral. Oecologia (Berlin) 68:358-366.

Fuentes, E. R., R. O. Otaiza, M. C. Alliende, A. Hoffman, and A. Poiani. 1984. Shrub clumps of the Chilean matorral vegetation: structure and possible maintenance mechanisms. Oecologia (Berlin) 62:405-411.

Garcia-Moya, E. and C. M. McKell. 1970. Contribution of shrubs to the nitrogen economy of a desert-wash plant community. Ecology 51:81-88.
Glendening, G. E. 1952. Some quantitative data on the increase of mesquite and cactus on a desert grassland range in southern Arizona. Ecology 33:319-328.

Glendening, G. E.1 and H. A. Paulsen. 1950. Recovery and viability of mesquite seeds fed to sheep receiving 2,4-D in drinking water. Botanical Gazette 111:486-491.

Guevara, S., S. E. Purata, and E. van der Maarel. 1986. The role of remnant forest trees in tropical secondary succession. Vegetatio 66:77-84.

Haas, R. H., R. E. Meyer, C. J. Scifres, and J. H. Brock. 1973. Growth and development of mesquite. Texas Agricultural Experiment Station Research Monograph 1:1019

Harrington, G. N., A. D. Wilson, and M. D. Young. 1984. Management of Australia's rangelands. Commonwealth Scientific and Industrial Research Organization, Melbourne, Australia.

Hastings, J. R., and R. M. Turner. 1965. The changing mile: an ecological study of vegetation change with time in the lower mile of an arid and semi-arid region. University of Arizona Press, Tucson, Arizona, USA.

Herbel, C. H. F. N. Ares, and R. A. Wright. 1972. Drought effects on a semidesert grassland range. Ecology 53:10841093 .

Hester, T. R. 1980. Digging into South Texas prehistory. Carona, San Antonio, Texas, USA.

Hill, M. O. 1979. DECORANA: a FORTRAN program for detrended correspondence analysis and reciprocal averaging. CornelI University, Ithaca, New York, USA.

Hooper, J., and R. A. Bullington. 1972. Invasion of woody plants in abandoned soil bank area of Pine Rock Preserve in Ogle County. Transactions of the Illinois State Academy of Science 65:58-67.

Humphrey, R. R. 1958. The desert grasslands: a history of vegetational change and an analysis of causes. Botanical Review 24: 193-252.

Hunt, R. 1978. Plant growth analysis. Edward Arnold, London, England.

Hunziker, J. H., R. A. Palacois, L. Paggio, C. A. Naranjo, and T. W. Yang. 1977. Geographic distribution, morphology, hybridization, cytogenetics and evolution. Pages $10-47$ in T. J. Mabry, J. H. Hunziker, and D. R. DiFeo, editors. Creosotebush: the biology and chemistry of Larrea in New World deserts. Dowden, Hutchinson and Ross, Stroudsburg, Pennsylvania, USA.

Inglis, J. 1964. A history of vegetation on the Rio Grande Plains. Texas Parks and Wildlife Department Bulletin 45, Austin, Texas, USA.

Janzen, D. H. 1970. Herbivores and the number of tree species in tropical forests. American Naturalist 104:501528.

Johnston, M. C. 1963. Past and present grasslands of southern Texas and northeastern Mexico. Ecology 44:456-466.

Kelly, R. D., and B. H. Walker. 1976. The effects of different forms of land use on the ecology of a semi-arid region of southeastern Rhodesia. Journal of Ecology 64:553-576.

Klemmedson, J. O., and A. R. Tiedemann. 1986. Longterm effects of mesquite removal on soil characteristics. II. Nutrient availability. Soil Science Society of America Journal 50:476-480.

Kuchler, A. W. 1964. The potential natural vegetation of the conterminous United States. American Geographical Society, New York, New York, USA.

Lehman, V. W. 1969. Forgotten legions: sheep in the Rio Grande Plains of Texas. Texas Western University Press, University of Texas, El Paso, Texas, USA.

Madany, M. H., and N. E. West. 1983. Livestock grazingfire regime interactions within montane forests of Zion $\mathrm{Na}$ tional Park, Utah. Ecology 64:661-667.

Maggia, R. C., and D. F. Wunneburger. 1986. A microcamputer-based geographic information system for natural re- 
source managers. Pages $\mathrm{l}-4$ in Conference proceedings: geographic information systems workshop. American Society of Photogrammetry and Remote Sensing, Falls Church, Virginia, USA.

Malin, J. C. 1953. Soil, animal and plant relations of the grassland, historically recorded. Scientific MonthIy 76:207220 .

McDonnelI, M. J.- and E. W. Stiles, 1983. The structural complexity of old field vegetation and the recruitment of bird-dispersed plant species. Oecologia (Berlin) 56:109-116.

Neilson, R. P. 1986. High resolution climatic analysis and Southwest biogeography. Science 232:27-34.

Norwine, J. 1978. Twentieth-century semi-arid climates and climatic fluctuations in Texas and northeastern Mexico. Journal of Arid Environments 1:313-325.

Palmer, E. 1871 . Food products of North American Indians. United States Commerce Department AgriculturaI Report 1870:404-428.

Peet, R. K. 1974. The measurement of species diversity. Annual Review of Ecology and Systematics 5:285-307.

Pemadasa, M. A. 1981. Cyclic change and pattem in an Arthrocnemum community in Sri Lanka. Journal of Ecology 69:565-574.

Preston, F. W. 1962. The canonical distribution of commonness and rarity. Ecology 43:185-215, 410-432.

San Jose, J. J., and M. R. Farinas. 1983. Changes in tree density and species composition in a protected Trachypogon savanna, Venezuela. Ecology 64:447-453.

SAS. 1982. SAS users guide: basics. SAS Institute, Cary, North Carolina, USA.

Scifres, C. J., and J. H. Brock. 1969. Moisture-temperature interrelations in germination and early seedling development of mesquite. Journal of Range Management 22:334337.

Scifres, C. J., and R. R. Hahn. 1971. Response of honey mesquite seedlings to top removal. Joumal of Range Management 24:296-298.

Scifres, C. J., C. R. Kienast, and D. J. Elrod. 1973. Honey mesquite seedling growth and susceptibility to 2,4,5-T as influenced by shading. Journal of Range Management 26 : 28-30.

Shearer, G., D. H. Kohl, R. A. Virginia, B. A. Bryan, J. L. Skeeters, E. T. Nilsen, M. R. Sharifi, and P. W. Rundel. 1983. Estimates of $\mathrm{N}_{2}$-fixation from variations in the natural abundance of ISN in Sonora Desert ecosystems. Oecologia (Berlin) 56:367-373.

Smeins, F. E. 1983. Origin of the brush problem-a geographical and ecological perspective of contemporary distributions. Pages 5-16 in Brush Management Symposium. Texas Tech Press, Lubbock, Texas, USA
Sokal, R. R., and F. J. Rohlf. 198I. Biometry. W. H. Freeman, New York, New York, USA.

Tharp, B. C. 1926. Structure of Texas vegetation east of the 98 th meridian. University of Texas Bulletin 2606.

Tiedemann, A. R., and J. O. Klemmedson. 1986. Longterm effects of mesquite removal of soil characteristics: I. Nutrients and bulk density. SoiI Science Society of America Joumal 50:472-475.

Tschirley, F. H., and S. C. Martin. 1960. Germination and langevity of velvet mesquite seed in soil. Journal of Range Management 13:94-97.

Ueckert, D. N., L. L. Smith, and B. L. Allen. 1979. Emergence and survival of honey mesquite seedlings on several soils in west Texas. Journal of Range Management 32:284287.

USDA (United States Department of Agriculture). 1979. Soil survey of Jim Wells County, Texas. United States Department of Agriculture/Soil Conservation Service, Washington, D.C., USA.

van Devender, T. R., and W. G. Spaulding. 1979. Development of vegetation and climate in the southwestern United States. Science 204:701-710.

van Vegten, J. A. 1983. Thombush invasion in a savanna ecosystem in eastern Botswana. Vegetatio 56:3-7.

Walter, H. 1979. Vegetation of the earth. Springer-Verlag, New York, New York, USA.

Webb, S. L., and M. F. Wilson 1985. Spatial heterogeneity in post-dispersal predation on Prunus and Uvularia seeds. Oecologia (Berlin) 67:150-153.

Whittaker, R. H., L. E. Gilbert, and J. H. Connell. 1979 a. Analysis of a two-phase pattern in a mesquite grassland, Texas. Journal of Ecology 67:935-952.

Whittaker, R. H., W. A. Niering, and M. D. Crisp. $1979 b$. Structure, pattern, and diversity of a Mallee community in New South Wales. Vegetatio 39:65-76.

Wright, H. A., S. C. Bunting, and L. F. Neuenschwander. 1976. Effect of fire on honey mesquite. Journal of Range Management 29:467-471.

Yarranton, G. A., and R. G. Marrison. 1974. Spatial dynamics of a primary succession: nucleation. Journal of Ecology 62:417-428.

Yeaton, R. I. 1978. A cyclical relationship between Larrea tridentata and Opunia leptocaulis in the northern Chihuahuan Desert. Journal of Ecology 66:65I-656.

Yeaton, R. L., and A. R. Manzanares. 1986. Organization of vegetation mosaics in the Acacia schaffneri-Opuntia streptacantha association, southern Chihuahuan Desert, Mexico. Journal of Ecology 74:211-217. 